\title{
STATUS OF AQUATIC RESOURCE AND PRODUCTION OF KONGSHA RIVER IN NORTHERN BANGLADESH
}

\author{
B. K. Chakraborty ${ }^{1 *}$ and M. Mome ${ }^{2}$ \\ ${ }^{1}$ Department of Fisheries, Bangladesh \& Bangladesh Agricultural University \\ ${ }^{2}$ Department of Fisheries, Bangladesh
}

*Corresponding author: bborty@gmail.com
Article Info:

Research Article

Received

03.12.2021

Reviewed

31.12.2021

Accepted

30.01.2022

\begin{abstract}
Bangladesh is very rich in aquatic biodiversity. The present study, conducted during 2016 to 2020, recorded a total number of 138 species (108 fish, 09 prawn, 01 snail, $05 \mathrm{crab}$, and 15 turtle) belonging to 22 families that identified from the Kongsha River and its flood plain. About ten types of fishing gears, different crafts, hook and line were identified operative in the river. Increasing rates of using current jal (15.00-25.80\%) and Bar jal (12.00-16.00\%) were identified as detrimental gears destroying different species. The productivity of aquatic life was decreased from $202.99 \pm 13.42$ to

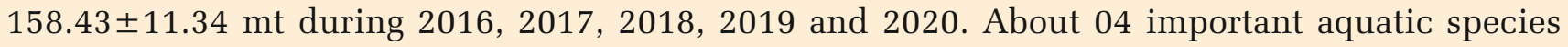
including major carp mohasseer (Tor tor), reptiles (Cyclemys oldhami, Melanocheelys trjuuga and Morenia petersi) became rare (E) and 17 commercially important aquatic species were at the edge of extinction (CR). From this exploration, 70 species were recorded in the endangered (EN) category, 21 species vulnerable (VU), 12 species lower risk (LR), 08 species least concern (LC) and 04 data deficient (DF). To save the existing aquatic species in the riverine ecosystem and ensure better livelihood of the fishes, a team of local management committee, similar to the Hilsa fisheries management technology is needed.
\end{abstract}

Keywords: Aquatic fauna, Biodiversity, Endangered, Extinct, Illegal fishing, Over exploitation.

Cite this article as: Chakraborty B. K. and Mome M. (2022). Status of Aquatic Resource and Production of Kongsha River in Northern Bangladesh. International Journal of Biological Innovations. 4(1): 1-15. https://doi.org/10.46505/IJBI.2022.4101.

\section{INTRODUCTION}

River ecosystem incorporates ecological, social and economic processes that interconnect organisms including humans and helpful in maintaining the biodiversity. The biodiversity supports in maintaining the ecological balance. There is a necessity of ecological balance for widespread biodiversity, human survival and sustainable development (Verma, 2018; Ashok,
2021). The biodiversity conservation and environmental ethics both are required for sustainable development and survival of plants and animals because biodiversity is the foundation of human life (Verma, 2019; Verma and Prakash, 2020).

The study of biodiversity has become a major concern to the fishing biologists and naturalists 
against the backdrop of rapid decline in the natural population of fish and aquatic biota across all the continents of the world. Biodiversity encompasses genetic, species, assemblage, ecosystem and land cape levels of biological organization with structural, compositional and functional components (Noss, 1990; Crains and Lackey, 1992). Though loss of aquatic species has been occurring rapidly, the aquatic organisms have received comparatively little attention from conservation biologists (Allendorf, 1988; Arya, 2021). A rich diversity of fish species is critical to the ecology and sustainable productivity of the flood plains (Praksh and Verma, 2020; Chakraborty et al., 2021a; Prakasah, 2021).

Fish is one of the major important elements in the aquatic habitat and play a major role in economy of nations (Okyere and Denis, 2011; Efe and Bemigho, 2021), as they have been a main item in the diet of general people. Nearly one billion people worldwide consume animal proteins (Marichamy et al., 2011). Throughout the world, rivers are the most modified and threatened in environments. Riverine fish communities show seasonal changes in the composition and relative abundance of species, which may be influenced by constant fluctuations in environmental factors (Thiel et al., 1995; Goswami et al., 2021).

Kangsha River is also known as the Kangsai or the Kangsabati (Nasrin Baby, 2012). The river is originated from the Garo Hills of India and flows as Kongsho, and later joined with the Shomeswari River at Jaria-Jhanjail. The former course of Kangsha River flows across the Nalitabari, Sherpur as the Bhogai River and JariaJhanjail, Netrakona as the Shomeswari River. It is a river in the northern parts of Mymensingh and Netrokona districts of Bangladesh. At Gaglajuri the Dhanu River is joined by the Kangsha. After Mohanganj it becomes a narrow winding khal with banks little higher than its own lowest level. The river flows past Barhatta, Mohanganj and Dharampasha (Fig. 1). The Kangsha flows into Surma River in Sunamganj

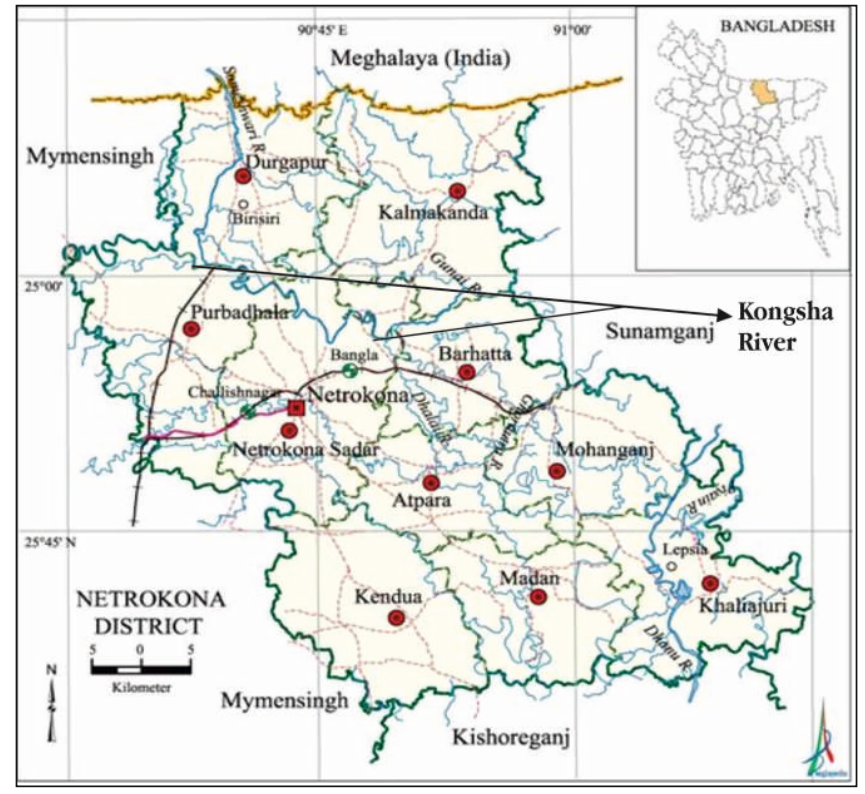

Fig. 1: Location of Kongsha River in the Netrokona district, Bangladesh.

Once upon a time, Kongsha River had an abundance of native wild fish, prawn, crab and reptile. Human activities, the conservation of aquatic biodiversity gained great intervention resulting in habitat loss and degradation and ecological importance over recent years. As a consequence, many fish species have become extremely endangered, particularly in rivers (Ali et al., 2014). Due to over-exploitation and various ecological changes in the Kongsha River, some important fish species, and reptiles disappeared. This river is under great stress and its existence is endangered because of the changing aquatic ecosystems. The downstream of the river system is siltated, which reduces the rate of water flow and causes habitat degradation. Like other floodplains, the feeding and breeding grounds of fishes in and around the Kongsha River have been reducing drastically from various human created problems. The resource of aquatic fauna Kongsha River is under severe threat due to overexploitation and environmental degradation, which includes human interventions through construction of flood control embankments, drainage structures and sluice gates, conversion of inundated land to cropland thereby reducing water area and indiscriminate use of pesticides.

The pollution from domestic, industrial and agrochemicals wastes and run off have resulted in extinction of a considerable amount of aquatic biota in same stretches of the open water system 
(Disaster, 1990; Alam, 1996). On the other hand, the indiscriminate use of different fishing gears, harmful techniques of fishing threaten the biodiversity of the seasonal floodplains also has negative impacts on fish diversity. Therefore, objective of this study was to provide an account of the diversity of aquatic lives and species composition in the Kongsha River. The finding of the study should be served as a baseline data for carrying out further study on the ecology, conservation and sustainability management of aquatic resources of the river.

\section{MATERIALS AND METHODS}

\section{Experimental design}

A part of Kangsha River was studied during 20162020 with particular emphasis on soil and water quality, biological productivity and status exploitation of the fishery resources. The river comprises an average length of $26-28 \mathrm{~km}$ long course with an average depth $6.87 \pm 0.33 \mathrm{~m}$. For the purpose of the study the river course was divided into upper and lower regions based on soil structure, water quality and fishing activities. The river courses of Jaria-Jhanjail to Deotukon and Deotukon to Barhatta constitute the lower region where Kongsha joins with the Bisnai River.

\section{Study of water quality parameters}

A bamboo made meter scale was used to measure water depth. Water temperature $\left({ }^{\circ} \mathrm{C}\right)$ was recorded using a Celsius thermometer and transparency (cm) was measured using a Secchi disc $(20 \mathrm{~cm}$ diameter). Dissolved oxygen (mg/l) and $\mathrm{pH}$ were measured directly using a digital electronic oxygen meter (YSI, Model 58, USA) and an electronic pH meter (Jenway, Model 3020, UK). Alkalinity was determined following the titrimetric method.

\section{Sampling of fish}

The investigation was conducted from 2016-2020 and was sampled simultaneously for winter (mid November to mid February), pre monsoon (mid February to April), monsoon (May to August) and post monsoon (September to mid November) for assessment of fish abundance and availability.

\section{Data collection}

The research was based on both primary and secondary data, comprehensive literature review and extracts of local knowledge and information. An organized sampling program spread over a reasonably long time is needed to get a true picture of the catch and composition. This study, being a rapid survey, gives only a broad picture of the stock of fishes, prawns, crabs and reptiles that could be obtained through market survey (JariaJhanjyle Bazar, Netrokona sadar Bazar, Barhatta Bazar, and Fokirer Bazar) and interaction with fisher's in the riverside and even in the river and secondary data were collected from the Department of Fisheries (DoF) and the internet. The number of six codes (CR, E, EN, VU, LR, LC and DD) of IUCN was followed to categorize the conservation of status of fishes recorded from the river and to compare the trend among Shannon index value of different years (Shannon, 1948).

\section{Shannon Diversity Index:}

$\mathrm{s}$
$\mathrm{H}=\sum-\left(\mathrm{Pi}^{*} \ln \mathrm{Pi}\right)$
$\mathrm{i}=1$

Where:

$\mathrm{H}=$ the Shannon diversity index

$\mathrm{Pi}=$ fraction of the entire population made up of species i,

$S=$ numbers of species encountered

$\Sigma=$ sum from species 1 to species $S$.

Note: The power to which the base e (e = 2.718281828) must be raised to obtain a number is called the natural logarithm (ln) of the number.

\section{Analysis of experimental data}

The data were analyzed through one way ANOVA using MSTAT followed by Duncan's Multiple Range Test to find out whether any significant difference existed among the different means (Zar, 1984).

\section{RESULTS AND DISCUSSION}

\section{Morphometry and hydrodynamics of experimental river}

Normally, there are three main sources of water input into the river ecosystem viz. overspill from the higher river channel, surface flow and regeneration. Water flows were determined by both rainfall and flooded water from the 
Meghalaya's hilly range, India. In upper region, the river originates from the hilly area of Maghaloya, India. Kongsha River is the northern part of Mymensingh and Netrokona. The Someshwari is one of the rivers that join it from the north. The river course was divided into two parts. Flow of Someshwari joins to Kongsha (Jaria-Jhanjyle) to Bharhatta through the Deotukon before joining the Bisnai River. Flooding of the river originated from the hilly area of Someswari River.

Surface run-off and increased in river height due to inflow of rainwater (flood) from the upper stretch, cause inundation of floodplains. The more water gain or exchange of water took place during southwest monsoon when floodplains were flooded. The early flood phase (April to early June) occurred in the early monsoon when the water level in basin was relatively low. The water level in the floodplain rises and falls depending on the water level in adjacent rivers. The deep flood phase (June to September) began when the water level in the river, causing deep flooding in the Durgapur, Sadar Netrokona and Bharhatta Upazilla. Floodwater in flood plains started receding in the post-monsoon season (October to December). The water loss by various means caused shrinkage of the effective water area and lowering of depth in the river which is very similar to the study of Chakraborty (2021a) and Chakraborty et al. (2021b).

\section{Physical characteristics}

Soil texture of the Kongsha River bed varied from sandy to loam sand. Soil texture of upper river bed was having $58.80 \pm 7.12$ sandy, $29.40 \pm 4.40$ loam sand and $11.80 \pm 3.02 \%$ clay. The dominance of sand (49.50 \pm 6.08$)$ and loam sand $(32.20 \pm 5.16)$ was also recorded in the lower

Table 1: Physical features of sediment of the Kongsha River.

\begin{tabular}{|l|c|c|c|}
\hline \multirow{2}{*}{ Location } & \multicolumn{3}{|c|}{ Soil texture of the river bed (\%) } \\
\cline { 2 - 4 } & Sandy & Loam sand & Clay \\
\hline Upper region & $58.80 \pm 7.12$ & $29.40 \pm 4.40$ & $11.80 \pm 3.02$ \\
Lower region & $49.50 \pm 6.08$ & $32.20 \pm 5.16$ & $18.30 \pm 4.04$ \\
\hline
\end{tabular}

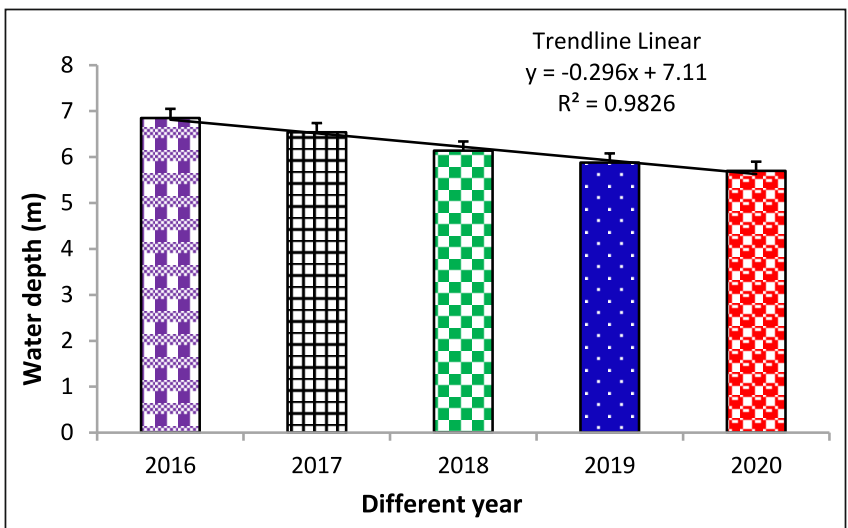

Fig. 2: Water depth of the Kongsha River between the year 2016 and 2020.

The highest depth of the river was recorded in the year 2016 and lowest depth was found in the year 2020, which exhibited a linear trend line and the equation of the trend line was $y=-0.296 x+7.11$ $\left(\mathrm{R}^{2}\right.$ is 0.9826$)$. The alarming trend of decrease in water depth (Fig. 2) was majorly due to rapid siltation.

\section{Physico-chemical parameters}

The observed values of the value of the physicochemical parameters of the river water are given in Table 2. The temperature, transparency, $\mathrm{pH}$, dissolved oxygen and alkalinity of water were found to be more or less in the desired range. The variations in mean water temperature of the river was not statistically significant $(\mathrm{P}>0.05)$. Water temperature of the river showed increasing trend in monsoon and post monsoon at $32.45^{\circ} \mathrm{C}$ and decreasing trend at $12.01^{\circ} \mathrm{C}$ in winter which was similar observation of Mathew (1975). Mean Secchi disk transparency differed significantly (P $<0.05$ ), during the study period. Higher values (31.11-49.88 cm) were recorded during post monsoon and summer months due to reduced flow and relatively stable conditions of water as observed by Rahman (1992). Transparency was consistently higher in upper region and in the deeper portion of the river. The $\mathrm{pH}$ of the studied river did not differ significantly $(\mathrm{P}>0.05)$. A significant rise in $\mathrm{pH}$ during pre-monsoon and a 
drop in winter were noted in the river (APHA, 1998). The mean dissolved oxygen (DO) did not differ significantly $(\mathrm{P}>0.05)$. The $\mathrm{pH}$ and oxygen values of the river agreed more or less similar with the findings of Boyd (1982). Water alkalinity levels were recorded medium to high as reported by (Clesceri et al., 1989). It differed significantly $(\mathrm{P}>0.05)$ with time. Lowest value $(110.77 \mathrm{mg} / \mathrm{L})$ of alkalinity was recorded in the in the winter during 2019.

Table 2: Physico-chemical parameters of experimental Kongsha River.

\begin{tabular}{|l|c|c|c|c|c|}
\hline \multirow{2}{*}{ Parameters } & \multicolumn{5}{|c|}{ Years } \\
\cline { 2 - 6 } & $\mathbf{2 0 1 6}$ & $\mathbf{2 0 1 7}$ & $\mathbf{2 0 1 8}$ & $\mathbf{2 0 1 9}$ & $\mathbf{2 0 2 0}$ \\
\hline Temperature $\left({ }^{\circ} \mathrm{C}\right)$ & $25.78 \pm 5.01$ & $25.86 \pm 4.12$ & $25.48 \pm 4.08$ & $25.88 \pm 5.23$ & $25.84 \pm 5.08$ \\
& $(12.84-32.45)$ & $(12.78-32.08)$ & $(12.01-31.80)$ & $(12.22-31.11)$ & $(12.55-32.07)$ \\
\hline Transparency $(\mathrm{cm})$ & $40.18 \pm 6.54^{\mathrm{b}}$ & $45.33 \pm 6.02^{\mathrm{c}}$ & $35.50 \pm 5.41^{\mathrm{a}}$ & $49.88 \pm 6.12^{\mathrm{d}}$ & $35.28 \pm 5.74^{\mathrm{a}}$ \\
& $(32.10-48.06)$ & $(30.02-50.44)$ & $(27.05-46.31)$ & $(34.33-55.55)$ & $(30.85-48.42)$ \\
\hline pH & $7.52 \pm 2.44$ & $7.76 \pm 3.22$ & $7.45 \pm 2.03$ & $7.58 \pm 1.28$ & $7.88 \pm 2.02$ \\
& $(5.70-8.88)$ & $(5.80-8.98)$ & $(5.85-9.77)$ & $(6.25-8.61)$ & $(6.55-8.82)$ \\
\hline Dissolved oxygen & $6.05 \pm 0.94$ & $6.04 \pm 1.01$ & $6.04 \pm 1.02$ & $7.01 \pm 1.02$ & $6.22 \pm 1.77$ \\
$(\mathrm{mg} / \mathrm{L})$ & $(4.55-8.04)$ & $(4.35-8.15)$ & $(4.44-7.66)$ & $(4.41-8.85)$ & $(5.04-8.08)$ \\
\hline Alkalinity (mg/L) & $139.82 \pm 10.04^{\mathrm{d}}$ & $121.36 \pm 8.22^{\mathrm{a}}$ & $130.11 \pm 7.05^{\mathrm{b}}$ & $135.32 \pm 8.87^{\mathrm{c}}$ & $145.16 \pm 9.24^{\mathrm{e}}$ \\
& $(101.32-140.05)$ & $(115.38-140.12)$ & $(112.25-147.15)$ & $(110.77-146.22)$ & $(114.11-150.55)$ \\
\hline
\end{tabular}

Figures with different superscripts in the same row varied significantly $(\mathrm{P}>0.05)$.

Figures in the parenthesis indicate the range.

\section{Capture method}

The fishers used wooden boats as a major crafts. They used seine net (Bar jal and Komor jal), Thela jal, Dharma jal, Bua jal, Lift net, Cast net, Current jal and various types of fish Trap, Hook and Line according to season and availability of different species of fishes. Wide variability in fish traps (vair, dugair, ghuni and pholo etc.) and hook and line (barshi, fulkuichi, Jhupi aikra etc.) were used to capture different groups of aquatic lives. During monsoon and post monsoon, fishers used lift net, Current jal, Cast net, Traps, and line and Hooks to catch fishes. Fishermen also operated kata fishing by seine net (Bar jal and Komor jal) in winter and spring.

Figure 3 shows a remarkable yearly increase in fishing effort by using illegal fishing gear like gill net (Current jal) and Bar jal (kaperi jal) in the total catch. The percentage of catch from Current jal were $15.00 \%, 17.50 \%, 21.00 \%, 23.00 \%$ and $25.8 \%$ and Bar jal (Kaperi jal) 12.00\%, 13.40\%, $14.80 \%, 15.20 \%$ and $16.00 \%$ in the years 2016 , 2017, 2018, 2019 and 2020, respectively. Significant difference in catch $(P<0.05)$ by Current jal and Bar jal (kaperi jal) were observed.

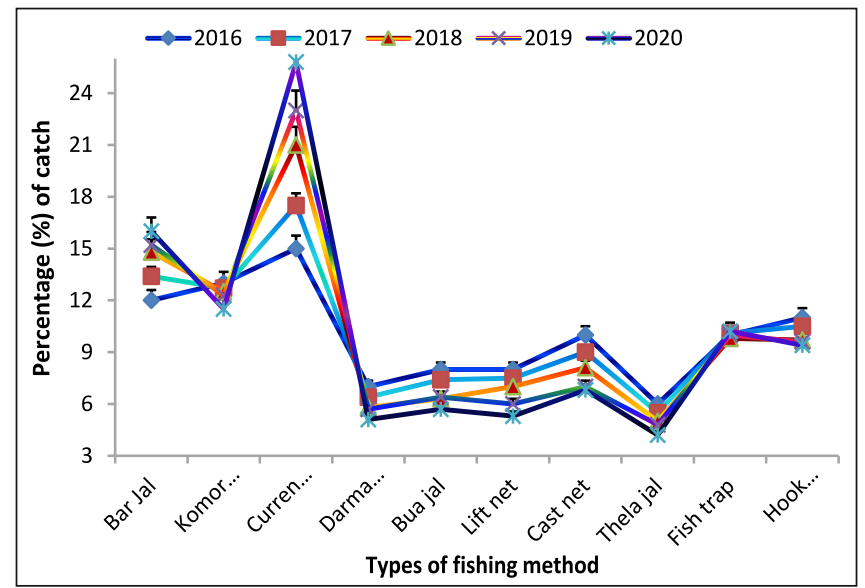

Fig. 3: Contribution of different fishing gears in Kongsha River during the study period (20162020).

The contribution of catch by Komor jal were $13.00 \%, 12.70 \%, 12.50 \%, 12.30 \%$ and $11.50 \%$ in the years 2016, 2017, 2018, 2019 and 2020, respectively.

Use of different fishing methods also differed significantly $(P<0.05)$. Haroon et al. (2002) reported eighteen types of fishing gears from the Sylhet sub-basin and thirteen types from Mymensingh sub-basin, Galib et al. (2009) 
reported 27 fishing gears and 2 fish aggregating devices in the Chalan Beel and Hussain (1999) found the fishing gears in the river Atrai and recorded 7 types of nets, 2 types of traps, 5 types of hook and line and 4 types of wounding fishing gears, which are very similar to this experiment. The catch using Thela jal, Dharma jal, Bua jal, Lift net, Cast net, fish Trap, and Hook and line were found decreasing trend and differed significantly $(P<0.05)$. A decreasing trend in the catch of the river and its flood plains were recorded and the findings were similar to that of Sugunan and Bhattacharya (2000) and Chakraborty (2021b).

\section{Fish catch and composition}

A sampling program was run for a long time to get a real picture of the catch and composition of the Kongsha River. The present investigation gave a broad picture of the stock of fishes and other aquatic lives obtained through landing center, market survey and interaction with fishers in the river. From the fishing activity in the Kongsha River, occurrence of 108 species of fish, 09 species of prawn, 01 species of snail and 05 species of crabs, and 15 species of turtles belonging to a total 22 families were recorded.

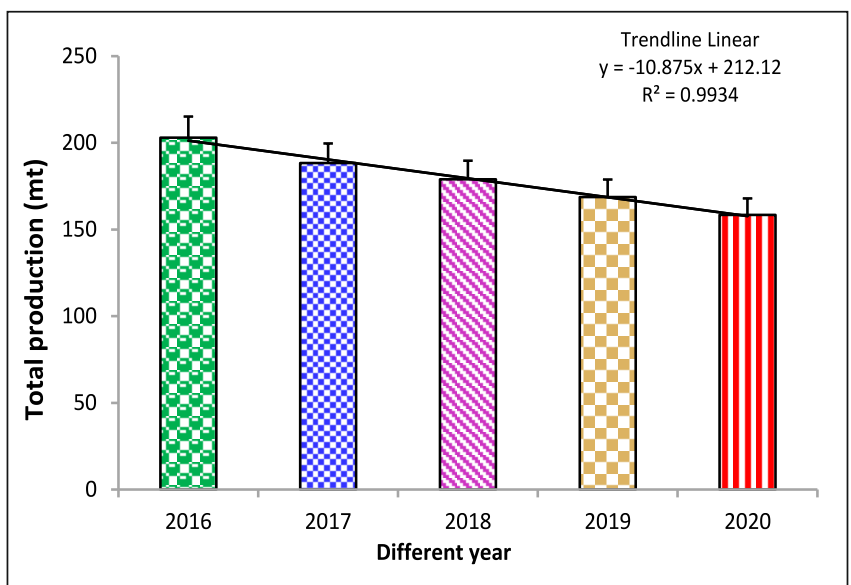

Fig.4. Total production of aquatic species in the Kongsha River between 2016 and 2020.

Fishing activity continued throughout the year. The annual catch assessment from the river was around $202.99 \pm 13.42, \quad 188.35 \pm 12.77$, $178.96 \pm 12.33,168.72 \pm 11.79$ and $158.43 \pm 11.34$ mt during 2016, 2017, 2018, 2019 and 2020 (Fig. 4), which exhibited a linear trend line and the equation was $\mathrm{y}=-10.875 \mathrm{x}+212.12$ (R2 $=0.9934)$. The catch consisted of snake head, major carp, minor carp, small fish, cat fish, small cat fish, eel, prawn, crabs and reptiles (Table ). Small fish was the dominant group (Fig. 5).

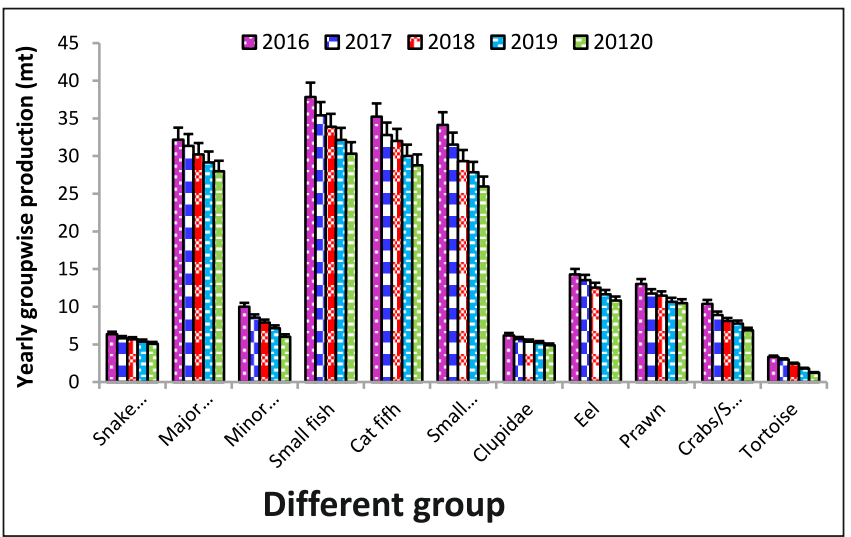

Fig. 5: The production of different groups of aquatic lives in the Kongsha River in the year 2016 to 2020.

The fish catch depicted a decrease in $7.21 \%$, $11.84 \%, 16.88 \%$ and $21.95 \%$ of catch in the years 2016-2017, 2017-2018, 2018-2019 and 20192020, with respect to the catch of 2016 (Fig. 6), which exhibited a linear trend line and the equation was $\mathrm{y}=4.926 \mathrm{x}+2.155(\mathrm{R} 2=$ 0.9934). A decrease trend in production from the river was clearly pronounced within the study period of five years which was similar to the observation of Chakraborty and Mirza (2007\& 2010) and Moyle and Leidy (1992).

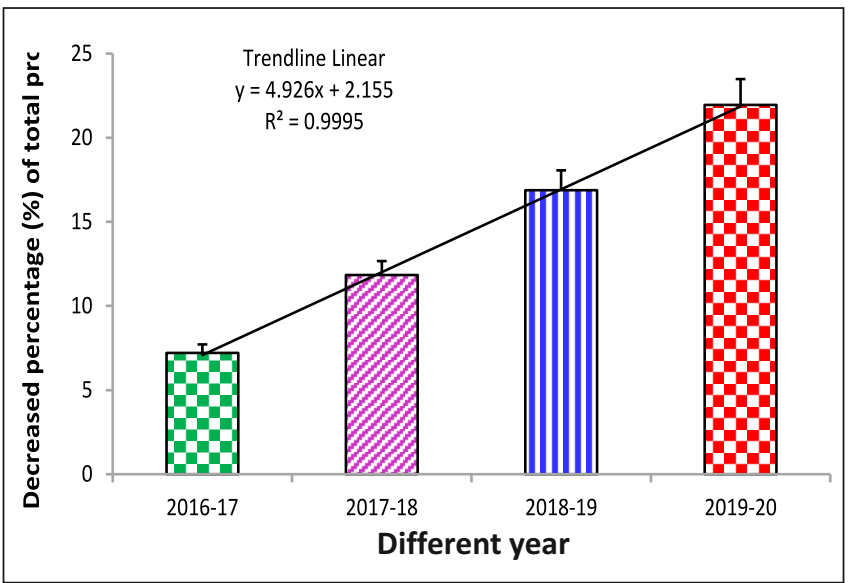

Fig. 6: Decreasing trend in the total production of aquatic lives in the Kongsha River during 2016 to 2020.

Small fishes were the dominant group in total catch followed by the cat fishes. Table 3 and the figure 7 exhibited the conservation status of the 139 aquatic wild animals of the Kongsha River and identified as E-04 (3\%), CR-17(12\%), 


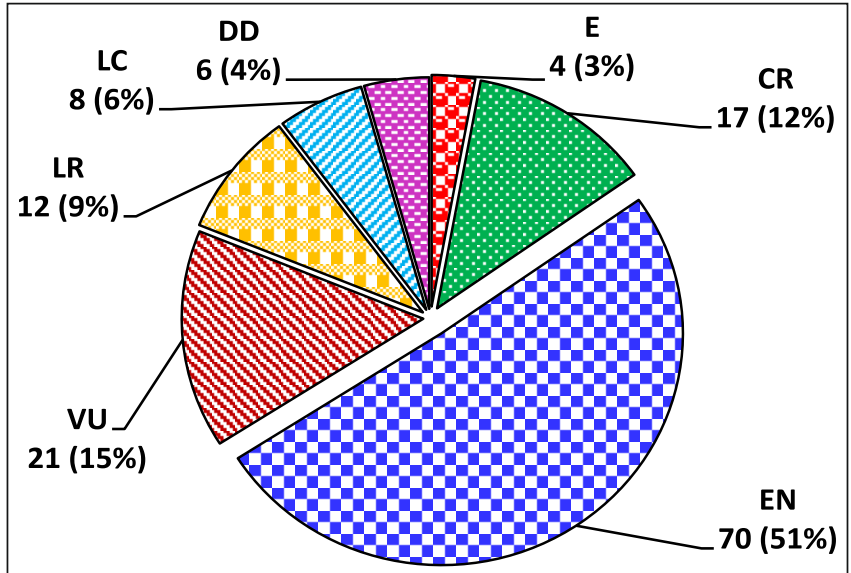

Fig. 7: Status of the recorded aquatic species in the Kongsha River.

EN-70(51\%), VU-21(15\%), LR-12(9\%), LC-08(9\%) and DD-06(4\%), respectively.

The total catch in different years differed significantly $(P<0.05)$. Commercial important Mohasseer (Tor tor), Pata Kachim, Cyclemys oldhami, Kali Kachhap, Melanocheelys trjuuga and Bengal Eyed Turtle, Morenia petersi were rarely found in the years 2016 to 2018 in the river. However these species were not recorded during 2020. Channa marulius, Tor putitora, Puntius sarana, Barilius tileo, Sicamugil casoasia, Rohtee cotio, Bagarius yarrellii, Mystus seenghala, Bagarius yarrellii, Chaca chaca, Rama chandramara, Sisor rabdophorus, Pseudolaguvia muricata, Pseudolaguvia inornata and reptiles (Indotestudo elongata, Batagur baska, Geoclemys hamiltonii and Pangshura tecta), a total of 17 species were reported as critically endangered and facing an extremely high risk of extinction in the river system (Table 3). According to IUCN (1998), in Bangladesh, about 56 freshwater fish species are critically or somewhat endangered. Due to overexploitation and various ecological changes in natural aquatic ecosystem of river and its flood plains, commercially important aquatic lives are in the verge of extinction which is in agreement with the findings of Sarker (1993).

The total catch data of the river exhibited a constant sharp decrease during 2016 and 2020. Some of the important native species were noted to be losing their presence. The capture of fishes, crab and reptiles in the river was recorded highest in 2016-17, but decreased considerably in 20182019 and the similar situation continued in 20192020. Small catfishes and small fishes are dominant groups caught from the river. The observation was similar to the findings of Chakraborty and Mirza (2007), Chakraborty (2009), Chakraborty (2021a) and Chakraborty et al. (2019 \& 2021b). As a result, commercially important four aquatic lives of river were recorded to be disappearing during this short 5 years experimental period.

Table 3: Status and distribution of Kongsha River of northern Bangladesh.

Status code: E-Extinct, CR-Critically Endangered, EN-Endangered, VU-Vulnerable, LR-Lower risk, LC-Not threatened DD=Data deficient (As per IUCN, 2000).

\begin{tabular}{|c|c|c|c|c|c|c|c|c|c|}
\hline \multirow[t]{3}{*}{ SL. No. } & \multirow[t]{3}{*}{ Group/ Family } & \multirow[t]{3}{*}{ Local name } & \multirow[t]{3}{*}{ Scientific name } & \multicolumn{5}{|c|}{ Production (mt) } & \multirow{3}{*}{ Status } \\
\hline & & & & \multicolumn{5}{|c|}{ Kongsha River } & \\
\hline & & & & 2016 & 2017 & 2018 & 2019 & 2020 & \\
\hline \multicolumn{10}{|c|}{ Snake headed } \\
\hline 1. & Notopteridae & Chitol & Notopterus chitala & $0.60 \pm 0.08$ & $0.58 \pm 0.06$ & $0.54 \pm 0.05$ & $0.51 \pm 0.04$ & $0.48 \pm 0.04$ & $\mathrm{EN}$ \\
\hline 2. & Notopteridae & Foli & $\begin{array}{l}\text { Notopterus } \\
\text { notopterus }\end{array}$ & $0.88 \pm 0.09$ & $0.62 \pm 0.06$ & $0.66 \pm 0.06$ & $0.58 \pm 0.04$ & $0.56 \pm 0.04$ & EN \\
\hline 3. & Belonidae & Kakila & Xenentodon cancila & $3.10 \pm 0.82$ & $3.02 \pm 0.81$ & $2.98 \pm 0.71$ & $2.85 \pm 0.66$ & $2.66 \pm 0.58$ & LR \\
\hline 4. & Channidae & Gojar & Channa marulius & $0.50 \pm 0.08$ & $0.45 \pm 0.07$ & $0.41 \pm 0.05$ & $0.39 \pm 0.04$ & $0.37 \pm 0.03$ & CR \\
\hline 5. & Channidae & Soal & Channa striata & $1.28 \pm 0.41$ & $1.14 \pm 0.39$ & $1.08 \pm 0.28$ & $1.04 \pm 0.25$ & $1.00 \pm 0.23$ & EN \\
\hline \multicolumn{4}{|c|}{ Sub Total } & $6.36 \pm 2.37$ & $5.81 \pm 2.30$ & $5.67 \pm 2.22$ & $5.37 \pm 2.11$ & $5.07 \pm 2.03$ & \\
\hline \multicolumn{10}{|c|}{ Major carps } \\
\hline 1. & Cyprinidae & Catla & Catla catla & $3.97 \pm 0.81$ & $3.83 \pm 0.75$ & $3.71 \pm 0.65$ & $3.57 \pm 0.64$ & $3.50 \pm 0.54$ & EN \\
\hline 2. & Cyprinidae & Rui & Labeo robita & $4.84 \pm 0.52$ & $4.69 \pm 0.51$ & $4.37 \pm 0.50$ & $4.40 \pm 0.49$ & $4.22 \pm 0.48$ & EN \\
\hline 3. & Cyprinidae & Mrigal & Cirrbinus mrigala & $4.66 \pm 0.86$ & $4.55 \pm 0.82$ & $4.44 \pm 0.81$ & $4.28 \pm 0.70$ & $4.12 \pm 0.60$ & EN \\
\hline 4. & Cyprinidae & Mahashol & Tot tor & $0.03 \pm 0.01$ & $0.01 \pm 0.01$ & $0.00 \pm 0.01$ & $0.00 \pm 0.0$ & $0.00 \pm 0.0$ & E \\
\hline
\end{tabular}




\begin{tabular}{|c|c|c|c|c|c|c|c|c|c|}
\hline 5. & Cyprinidae & Mahashol & Tot putitora & $0.02 \pm 0.01$ & $0.01 \pm 0.01$ & $0.01 \pm 0.0$ & $0.008 \pm 0.0$ & $0.001 \pm 0.0$ & $\mathrm{CR}$ \\
\hline 6. & Cyprinidae & Kalbaus & Labeo calbasu & $5.29 \pm 0.89$ & $5.20 \pm 0.88$ & $5.11 \pm 0.87$ & $5.04 \pm 0.77$ & $4.94 \pm 0.75$ & EN \\
\hline 7. & Cyprinidae & Ghonia & Labeo gonius & $2.40 \pm 0.58$ & $2.28 \pm 0.55$ & $2.18 \pm 0.44$ & $2.06 \pm 0.42$ & $1.99 \pm 0.40$ & EN \\
\hline 8. & Cyprinidae & Reba & Cirrbinus reba & $1.00 \pm 0.11$ & $0.94 \pm 0.10$ & $0.88 \pm 0.08$ & $0.82 \pm 0.07$ & $0.80 \pm 0.06$ & EN \\
\hline 9. & Cyprinidae & Common carp & Cyprinus carpio & $7.30 \pm 1.94$ & $7.30 \pm 1.70$ & $7.08 \pm 1.41$ & $6.60 \pm 1.31$ & $6.32 \pm 1.20$ & $\mathrm{VU}$ \\
\hline 10. & Cyprinidae & Grass carp & $\begin{array}{l}\text { Ctenopharyngodon } \\
\text { idella }\end{array}$ & $2.66 \pm 1.41$ & $2.55 \pm 1.33$ & $2.44 \pm 1.22$ & $2.37 \pm 1.11$ & $2.09 \pm 0.98$ & $\mathrm{VU}$ \\
\hline \multicolumn{4}{|c|}{ Sub-Total } & $32.17 \pm 8.26$ & $31.36 \pm 8.03$ & $30.22 \pm 8.10$ & $29.15 \pm 7.66$ & $27.98 \pm 6.62$ & \\
\hline \multicolumn{10}{|c|}{ Minor carps } \\
\hline 1. & Cyprinidae & Along & Bengala elanga & $2.90 \pm 0.09$ & $2.10 \pm 0.08$ & $1.94 \pm 0.07$ & $1.82 \pm 0.06$ & $1.75 \pm 0.04$ & $\mathrm{VU}$ \\
\hline 2. & Cyprinidae & Bhangna bata & Labeo bata & $2.10 \pm 0.55$ & $2.00 \pm 0.25$ & $1.80 \pm 0.15$ & $1.65 \pm 0.14$ & $1.55 \pm 0.12$ & EN \\
\hline 3. & Cyprinidae & Ghora muikha & Labeo pangusia & $0.91 \pm 0.05$ & $0.80 \pm 0.04$ & $0.74 \pm 0.03$ & $0.62 \pm 0.03$ & $0.57 \pm 0.02$ & EN \\
\hline 4. & Cyprinidae & Jarua/Utti & Chagunius chagunio & $0.97 \pm 0.05$ & $0.84 \pm 0.04$ & $0.75 \pm 0.04$ & $0.68 \pm 0.03$ & $0.62 \pm 0.02$ & EN \\
\hline 5. & Cyprinidae & Puda & Puntius sarana & $1.07 \pm 0.07$ & $1.04 \pm 0.06$ & $1.01 \pm 0.05$ & $0.90 \pm 0.04$ & $0.22 \pm 0.03$ & $\mathrm{CR}$ \\
\hline 6. & Cypriidae & Tila koksa & Barilius tileo & $1.10 \pm 0.08$ & $0.95 \pm 0.06$ & $0.88 \pm 0.05$ & $0.77 \pm 0.03$ & $0.64 \pm 0.02$ & $\mathrm{EN}$ \\
\hline 7. & Cyprinidae & Bhol & Raimass bola & $0.96 \pm 0.05$ & $0.82 \pm 0.04$ & $0.77 \pm 0.04$ & $0.72 \pm 003$ & $0.68 \pm 0.02$ & $\mathrm{EN}$ \\
\hline \multicolumn{4}{|c|}{ Sub-Total } & $10.01 \pm 0.21$ & $8.55 \pm 0.22$ & $7.89 \pm 0.22$ & $7.16 \pm 0.22$ & $6.03 \pm 0.20$ & \\
\hline \multicolumn{10}{|c|}{ Small fish } \\
\hline 1. & Cyprinidae & Mola & $\begin{array}{l}\text { Amblypharyngodon } \\
\text { mola }\end{array}$ & $1.88 \pm 0.05$ & $1.70 \pm 0.04$ & $1.64 \pm 0.04$ & $1.56 \pm 0.04$ & $1.48 \pm 0.03$ & EN \\
\hline 2. & Cyprinidae & Barna Baril/ Koksa & Barilius barna & $0.85 \pm 0.04$ & $0.78 \pm 0.03$ & $0.72 \pm 0.03$ & $0.67 \pm 0.02$ & $0.64 \pm 0.03$ & EN \\
\hline 3. & Cyprinidae & Baril & Barilius bendelisis & $0.51 \pm 0.02$ & $0.48 \pm 0.01$ & $0.44 \pm 0.01$ & $0.41 \pm 001$ & $0.38 \pm 0.01$ & EN \\
\hline 4. & Cyprinidae & Koksa & Barilius shacra & $0.60 \pm 0.04$ & $0.52 \pm 0.02$ & $0.55 \pm 0.02$ & $0.53 \pm 0.02$ & $0.52 \pm 0.01$ & EN \\
\hline 5. & Cyprinidae & Koksa & Barilius tileo & $0.82 \pm 0.03$ & $0.73 \pm 0.03$ & $0.69 \pm 0.02$ & $0.66 \pm 0.01$ & $0.61 \pm 0.0$ & $\mathrm{CR}$ \\
\hline 6. & Cyprinidae & Aspidopara/Morar & Aspidoparia morar & $0.60 \pm 0.04$ & $0.58 \pm 0.04$ & $0.53 \pm 0.03$ & $0.48 \pm 0.02$ & $0.44 \pm 0.01$ & EN \\
\hline 7. & Cyprinidae & Chepchela & Chela cachius & $0.80 \pm 0.06$ & $0.81 \pm 0.06$ & $0.70 \pm 0.06$ & $0.66 \pm 0.05$ & $0.60 \pm 0.03$ & EN \\
\hline 8. & Cyprinidae & Kashkhaira & Chela laubuca & $0.80 \pm 0.05$ & $0.78 \pm 0.03$ & $0.76 \pm 0.04$ & $0.70 \pm 0.03$ & $0.68 \pm 0.03$ & EN \\
\hline 9. & Mugillidae & Kachi Kholya & Sicamugil casoasia & $0.72 \pm 0.02$ & $0.74 \pm 0.01$ & $0.71 \pm 0.01$ & $0.70 \pm 001$ & $0.69 \pm 0.01$ & $\mathrm{CR}$ \\
\hline 10. & Cyprinidae & Baspata & Danio devario & $0.82 \pm 0.04$ & $0.80 \pm 0.04$ & $0.78 \pm 0.03$ & $0.72 \pm 0.03$ & $0.73 \pm 0.01$ & EN \\
\hline 11. & Cyprinidae & Dhela & Robtee cotio & $0.70 \pm 0.03$ & $0.62 \pm 0.03$ & $0.64 \pm 0.02$ & $0.60 \pm 0.01$ & $0.54 \pm 0.0$ & $\mathrm{CR}$ \\
\hline 12. & Cyprinidae & Chola punti & Puntius chola & $0.54 \pm 0.04$ & $0.50 \pm 0.04$ & $0.48 \pm 0.03$ & $0.40 \pm 0.02$ & $0.43 \pm 0.01$ & EN \\
\hline 13. & Cyprinidae & Taka punti & Puntius conchonius & $0.64 \pm 0.06$ & $0.58 \pm 0.05$ & $0.55 \pm 0.04$ & $0.50 \pm 0.03$ & $0.44 \pm 0.02$ & $\mathrm{EN}$ \\
\hline 14. & Cyprinidae & Phutani punti & Puntius phutunio & $0.80 \pm 0.05$ & $0.75 \pm 0.05$ & $0.74 \pm 0.02$ & $0.78 \pm 0.02$ & $0.62 \pm 0.01$ & EN \\
\hline 15. & Cyprinidae & Jatpunti Punti & Puntius Sophore & $0.54 \pm 0.03$ & $0.48 \pm 0.03$ & $0.44 \pm 0.02$ & $0.42 \pm 0.02$ & $0.40 \pm 0.01$ & EN \\
\hline 16. & Cyprinidae & Teri punti & Puntius terio & $0.80 \pm 0.05$ & $0.74 \pm 0.04$ & $0.78 \pm 0.03$ & $0.70 \pm 0.02$ & $0.68 \pm 0.02$ & $\mathrm{EN}$ \\
\hline 17. & Cyprinidae & Tit Punti & Puntius ticto & $0.73 \pm 0.06$ & $0.70 \pm 0.05$ & $0.65 \pm 0.04$ & $0.60 \pm 0.03$ & $0.55 \pm 0.01$ & $\mathrm{VU}$ \\
\hline 18. & Cyprinidae & Fulchela & Salmostoma phulo & $0.92 \pm 0.04$ & $0.88 \pm 0.03$ & $0.80 \pm 0.02$ & $0.75 \pm 0.02$ & $0.70 \pm 0.01$ & $\mathrm{EN}$ \\
\hline 19. & Cyprinidae & Darkina & Esomus danricus & $0.70 \pm 0.03$ & $0.62 \pm 0.03$ & $0.67 \pm 0.02$ & $0.62 \pm 0.02$ & $0.59 \pm 0.01$ & $\mathrm{VU}$ \\
\hline 20. & Cyprinidae & Kanpona & Oryzias melastigma & $0.40 \pm 0.03$ & $0.35 \pm 0.03$ & $0.32 \pm 0.03$ & $0.29 \pm 0.02$ & $0.16 \pm 0.01$ & $\mathrm{VU}$ \\
\hline 21. & Clupeidae & Kachki & Corica soborna & $0.90 \pm 0.07$ & $0.84 \pm 0.06$ & $0.83 \pm 0.05$ & $0.70 \pm 0.04$ & $0.71 \pm 0.04$ & $\mathrm{DD}$ \\
\hline 22. & Cobitidae & Balitora & $\begin{array}{l}\text { Psilorbynchus } \\
\text { balitora }\end{array}$ & $0.80 \pm 0.04$ & $0.77 \pm 0.04$ & $0.73 \pm 0.03$ & $0.76 \pm 0.02$ & $0.70 \pm 0.03$ & EN \\
\hline 23. & Cobitidae & Balitora & $\begin{array}{l}\text { Psilorbynchus } \\
\text { rabmani }\end{array}$ & $0.70 \pm 0.02$ & $0.66 \pm 0.01$ & $0.62 \pm 0.01$ & $0.59 \pm 001$ & $0.58 \pm 0.01$ & $\mathrm{LC}$ \\
\hline 24. & Cobitidae & $\begin{array}{l}\text { River stone carp/ } \\
\text { Titari }\end{array}$ & $\begin{array}{l}\text { Psilorbynchus } \\
\text { sucatio }\end{array}$ & $0.80 \pm 0.04$ & $0.76 \pm 0.03$ & $0.74 \pm 0.03$ & $0.70 \pm 0.02$ & $0.65 \pm 0.02$ & EN \\
\hline 25. & Cobitidae & Bilturi/Bali chata & Acanthocobitis botia & $0.60 \pm 0.02$ & $0.56 \pm 0.01$ & $0.51 \pm 0.01$ & $0.48 \pm 001$ & $0.45 \pm 0.01$ & EN \\
\hline
\end{tabular}




\begin{tabular}{|c|c|c|c|c|c|c|c|c|c|}
\hline 26. & Cobitidae & $\begin{array}{l}\text { River loach/ } \\
\text { Balichata }\end{array}$ & $\begin{array}{l}\text { Acanthocobitis } \\
\text { zonalternans }\end{array}$ & $0.86 \pm 0.03$ & $0.80 \pm 0.02$ & $0.79 \pm 0.02$ & $0.72 \pm 0.02$ & $0.73 \pm 0.01$ & $\mathrm{VU}$ \\
\hline 27. & Cobitidae & Koirka & Nemacheilus corica & $0.88 \pm 0.03$ & $0.81 \pm 0.03$ & $0.79 \pm 0.02$ & $0.70 \pm 0.01$ & $0.69 \pm 0.0$ & LR \\
\hline 28. & Cobitidae & Creek loach & Schistura beavani & $0.64 \pm 0.04$ & $0.60 \pm 0.04$ & $0.57 \pm 0.03$ & $0.56 \pm 0.02$ & $0.52 \pm 0.01$ & $\mathrm{VU}$ \\
\hline 29. & Cobitidae & Corica Loach/Korika & Schistura corica & $0.84 \pm 0.06$ & $0.78 \pm 0.05$ & $0.75 \pm 0.04$ & $0.73 \pm 0.04$ & $0.68 \pm 0.03$ & LR \\
\hline 30. & Cobitidae & Savon khorka & Schistura savona & $0.73 \pm 0.04$ & $0.70 \pm 0.03$ & $0.71 \pm 0.02$ & $0.68 \pm 0.02$ & $0.64 \pm 0.01$ & LR \\
\hline 31. & Cobitidae & Dari & Schistura scaturigina & $0.63 \pm 0.03$ & $0.62 \pm 0.03$ & $0.58 \pm 0.02$ & $0.54 \pm 0.02$ & $0.48 \pm 0.01$ & EN \\
\hline 32. & Cobitidae & $\begin{array}{l}\text { Bengal loach / } \\
\text { Bou mach }\end{array}$ & Botia dario & $0.64 \pm 0.04$ & $0.60 \pm 0.04$ & $0.58 \pm 0.03$ & $0.56 \pm 0.02$ & $0.53 \pm 0.02$ & $\mathrm{VU}$ \\
\hline 33. & Cobitidae & Hora loach & Botia dayi & $0.51 \pm 0.04$ & $0.50 \pm 0.03$ & $0.45 \pm 0.03$ & $0.38 \pm 0.03$ & $0.32 \pm 0.01$ & EN \\
\hline 34. & Cobitidae & Loach/Puiya & $\begin{array}{l}\text { Lepidocephalichthys } \\
\text { goalparensis }\end{array}$ & $0.72 \pm 0.04$ & $0.68 \pm 0.03$ & $0.62 \pm 0.02$ & $0.58 \backslash \pm 0.02$ & $0.54 \pm 0.01$ & $\mathrm{EN}$ \\
\hline 35. & Cobitidae & Goalpara loach & $\begin{array}{l}\text { Neoeucirrbichthys } \\
\text { maydelli }\end{array}$ & $0.55 \pm 0.04$ & $0.52 \pm 0.03$ & $0.48 \pm 0.02$ & $0.46 \pm 0.02$ & $0.44 \pm 0.01$ & EN \\
\hline 36. & Cobitidae & $\begin{array}{l}\text { Gonga loach/Poia/ } \\
\text { Ghar poia }\end{array}$ & Somileptes gongota & $0.51 \pm 0.06$ & $0.47 \pm 0.05$ & $0.48 \pm 0.04$ & $0.47 \pm 0.03$ & $0.44 \pm 0.01$ & $\mathrm{vU}$ \\
\hline 37. & Cobitidae & Rani & Botia lobachata & $0.52 \pm 0.04$ & $0.50 \pm 0.04$ & $0.48 \pm 0.03$ & $0.46 \pm 0.03$ & $0.43 \pm 0.01$ & LR \\
\hline 38. & Cobitidae & Rani & $\begin{array}{l}\text { Lepidocephalichthys } \\
\text { annandalei }\end{array}$ & $0.75 \pm 0.03$ & $0.72 \pm 0.03$ & $0.68 \pm 0.02$ & $0.64 \pm 0.02$ & $0.60 \pm 0.01$ & EN \\
\hline 39. & Cobitidae & Balichata & Nemachilus botia & $0.66 \pm 0.04$ & $0.62 \pm 0.02$ & $0.60 \pm 0.02$ & $0.54 \pm 0.01$ & $0.51 \pm 0.01$ & EN \\
\hline 40. & Centropomidae & Chanda & Chanda nama & $2.20 \pm 0.08$ & $1.89 \pm 0.05$ & $1.71 \pm 0.04$ & $1.67 \pm 004$ & $1.54 \pm 0.03$ & $\mathrm{LC}$ \\
\hline 41. & Centropomidae & Chanda & $\begin{array}{l}\text { Pseudambasis } \\
\text { bacuculis }\end{array}$ & $1.85 \pm 0.07$ & $1.63 \pm 0.05$ & $1.55 \pm 0.04$ & $1.52 \pm 0.03$ & $1.47 \pm 0.04$ & EN \\
\hline 42. & Centropomidae & Ranga chanda & Pseudambasis ranga & $0.66 \pm 0.03$ & $0.62 \pm 0.03$ & $0.60 \pm 0.02$ & $0.61 \pm 0.02$ & $0.58 \pm 0.01$ & LC \\
\hline 43. & Gobiidae & Baila & Glossogobus giuris & $2.92 \pm 0.07$ & $2.86 \pm 0.05$ & $2.77 \pm 0.05$ & $2.69 \pm 0.05$ & $2.62 \pm 0.04$ & DD \\
\hline 44. & Tetradontidae & Potka & Tetradon cutcutia & $1.82 \pm 0.08$ & $1.75 \pm 0.06$ & $1.70 \pm 0.05$ & $1.65 \pm 0.04$ & $1.60 \pm 0.04$ & EN \\
\hline \multicolumn{4}{|c|}{ Sub-Total } & $37.86 \pm 0.22$ & $35.40 \pm 0.19$ & $33.91 \pm 0.17$ & $32.14 \pm 0.17$ & $30.33 \pm 0.16$ & \\
\hline \multicolumn{10}{|c|}{ Cat fish } \\
\hline 1. & Bagridae & Ayre & Mystus aor & $5.98 \pm 0.18$ & $4.80 \pm 0.12$ & $4.68 \pm 0.14$ & $4.32 \pm 0.11$ & $4.00 \pm 0.09$ & EN \\
\hline 2. & Bagridae & Guizza & Mystus seenghala & $5.86 \pm 0.22$ & $5.55 \pm 0.18$ & $4.90 \pm 0.11$ & $4.29 \pm 0.10$ & $4.19 \pm 0.10$ & $\mathrm{CR}$ \\
\hline 3. & Schilbeidae & Shilong & Silonia silondia & $1.88 \pm 0.06$ & $1.63 \pm 0.04$ & $1.58 \pm 0.04$ & $1.52 \pm 0.03$ & $1.45 \pm 0.02$ & EN \\
\hline 4. & Siluridae & Boal & Wallago attu & $7.58 \pm 1.24$ & $7.22 \pm 1.11$ & $7.06 \pm 1.01$ & $6.72 \pm 1.00$ & $6.44 \pm 1.00$ & LR \\
\hline 5. & Bagridae & Baghair & Bagarius yarrellii & $4.08 \pm 1.10$ & $3.66 \pm 0.88$ & $3.20 \pm 0.78$ & $3.15 \pm 0.67$ & $3.00 \pm 0.55$ & $\mathrm{CR}$ \\
\hline 6. & Chacidae & Cheka & Chaca chaca & $0.95 \pm 0.08$ & $0.88 \pm 0.07$ & $0.87 \pm 0.07$ & $0.82 \pm 0.05$ & $0.85 \pm 0.04$ & CR \\
\hline 7. & Bagridae & Gangmagur & Mystus menoda & $4.85 \pm 0.98$ & $4.17 \pm 0.88$ & $4.90 \pm 0.88$ & $4.55 \pm 0.77$ & $4.41 \pm 0.66$ & EN \\
\hline 8. & Bagridae & Rita & Rita rita & $4.05 \pm 0.95$ & $4.90 \pm 0.86$ & $4.82 \pm 0.70$ & $4.65 \pm 0.55$ & $4.44 \pm 0.38$ & EN \\
\hline \multicolumn{4}{|c|}{ Sub total } & $35.23 \pm 1.22$ & $32.81 \pm 1.13$ & $32.01 \pm 1.09$ & $30.02 \pm 1.01$ & $28.78 \pm 0.95$ & \\
\hline \multicolumn{10}{|c|}{ Small cat fish } \\
\hline 1. & Bagridae & Gulsa & Mystus cavasius & $2.80 \pm 0.01$ & $2.60 \pm 0.11$ & $2.22 \pm 0.08$ & $2.11 \pm 0.07$ & $1.99 \pm 0.06$ & EN \\
\hline 2. & Bagridae & Tengra & Mystus vitttus & $2.70 \pm 0.11$ & $2.50 \pm 0.11$ & $2.44 \pm 0.10$ & $2.33 \pm 0.10$ & $2.20 \pm 0.08$ & EN \\
\hline 3. & Bagridae & Bujuri & Mystus tengra & $3.66 \pm 0.11$ & $3.54 \pm 0.11$ & $3.48 \pm 0.08$ & $3.36 \pm 0.07$ & $3.28 \pm 0.06$ & $\mathrm{VU}$ \\
\hline 4. & Bagridae & $\begin{array}{l}\text { Gura Tengra/ } \\
\text { Futki bujuri }\end{array}$ & Rama chandramara & $0.90 \pm 0.06$ & $0.80 \pm 0.04$ & $0.70 \pm 0.03$ & $0.68 \pm 0.03$ & $0.59 \pm .0 .02$ & $\mathrm{CR}$ \\
\hline 5. & Bagridae & $\begin{array}{l}\text { Menoda catfish/ } \\
\text { Arwari }\end{array}$ & Hemibagrus menoda & $0.95 \pm 0.07$ & $0.80 \pm 0.05$ & $0.74 \pm 0.05$ & $0.68 \pm 0.04$ & $0.59 \pm 0.02$ & EN \\
\hline \multirow[t]{2}{*}{6.} & Bagridae & Kerala mystus & Mystus armatus & $0.90 \pm 0.04$ & $0.89 \pm 0.04$ & $0.88 \pm 0.03$ & $0.78 \pm 0.03$ & $0.69 \pm .0 .02$ & EN \\
\hline & Bagridae & Day's mystus/Tengra & Mystus bleekeri & $0.75 \pm 0.07$ & $0.66 \pm 0.05$ & $0.60 \pm 0.05$ & $0.58 \pm 0.04$ & $0.52 \pm 0.02$ & EN \\
\hline 7. & Schilbeidae & Kajuli & Ailia coila & $1.0 \pm 0.08$ & $0.96 \pm 0.07$ & $0.86 \pm 0.06$ & $0.82 \pm 0.05$ & $0.74 \pm 0.04$ & EN \\
\hline 8. & Siluridae & Kani Pabda & Ompok bimaculatus & $2.07 \pm 0.08$ & $2.02 \pm 0.07$ & $2.01 \pm 0.06$ & $2.00 \pm 0.06$ & $1.97 \pm 0.05$ & EN \\
\hline
\end{tabular}




\begin{tabular}{|c|c|c|c|c|c|c|c|c|c|}
\hline 9. & Siluridae & Madhu Pabda & Ompok pabda & $2.04 \pm 0.09$ & $2.00 \pm 0.08$ & $1.92 \pm 0.07$ & $1.82 \pm 0.06$ & $1.78 \pm 0.05$ & $\mathrm{VU}$ \\
\hline 10. & Siluridae & Ompok pabda & Ompokpabo & $1.88 \pm 0.07$ & $1.77 \pm 0.06$ & $1.70 \pm 0.06$ & $1.65 \pm 0.04$ & $1.60 \pm 0.04$ & $\mathrm{EN}$ \\
\hline 11. & Schilbeidae & Gharua & Clupisoma garua & $1.87 \pm 0.08$ & $1.40 \pm 0.06$ & $1.33 \pm 0.07$ & $1.23 \pm 0.07$ & $1.01 \pm 0.05$ & EN \\
\hline 12. & Schilbeidae & Muri Bacha & Clupisoma murias & $0.88 \pm 0.05$ & $0.82 \pm 0.05$ & $0.75 \pm 0.05$ & 0.670 .04 & $0.62 \pm 0.03$ & EN \\
\hline 13. & Schilbeidae & Batasi & $\begin{array}{l}\text { Pseudeutropius } \\
\text { atherinoides }\end{array}$ & $1.70 \pm 0.06$ & $1.66 \pm 0.04$ & $1.60 \pm 0.03$ & $1.50 \pm 0.03$ & $1.44 \pm .0 .02$ & $\mathrm{vU}$ \\
\hline 14. & Schilbeidae & Bacha & Eutropiichthys vacha & $1.40 \pm 0.07$ & $1.33 \pm 0.05$ & $1.24 \pm 0.05$ & $1.22 \pm 0.04$ & $1.15 \pm 0.02$ & EN \\
\hline 15. & Sisoridae & Kutakanti & Hara bara & $0.80 \pm 0.04$ & $0.75 \pm 0.04$ & $0.69 \pm 0.04$ & $0.65 \pm 0.04$ & $0.64 \pm 0.04$ & LR \\
\hline 16. & Sisoridae & Kutakanti & Hara jerdoni & $1.17 \pm 0.08$ & $0.98 \pm 0.06$ & $0.92 \pm 0.07$ & $0.90 \pm 0.07$ & $0.88 \pm 0.05$ & EN \\
\hline 17. & Sisoridae & Gang tengra & Nangra nangra & $0.48 \pm 0.04$ & $0.42 \pm 0.04$ & $0.35 \pm 0.04$ & 0.360 .04 & $0.32 \pm 0.03$ & $\mathrm{VU}$ \\
\hline 18. & Sisoridae & Chenua & Sisor rabdophorus & $0.42 \pm 0.03$ & $0.38 \pm 0.03$ & $0.27 \pm 0.03$ & $0.20 \pm 0.02$ & $0.17 \pm .0 .01$ & $\mathrm{CR}$ \\
\hline 19. & Sisoridae & $\begin{array}{l}\text { Conta catfish/ } \\
\text { Kuta kanti }\end{array}$ & Conta conta & $0.45 \pm 0.03$ & $0.40 \pm 0.03$ & $0.34 \pm 0.03$ & $0.33 \pm 0.04$ & $0.29 \pm 0.02$ & $\mathrm{DD}$ \\
\hline 20. & Sisoridae & Kani Tengra & $\begin{array}{l}\text { Pseudolaguvia } \\
\text { muricata }\end{array}$ & $0.45 \pm 0.04$ & $0.40 \pm 0.03$ & $0.36 \pm 0.04$ & $0.23 \pm 0.03$ & $0.12 \pm 0.02$ & CR \\
\hline 21. & Sisoridae & Chanua & $\begin{array}{l}\text { Pseudolaguvia } \\
\text { inornata }\end{array}$ & $0.41 \pm 0.01$ & $0.30 \pm 0 . .01$ & $0.21 \pm 0.01$ & $0.16 \pm 0.01$ & $0.08 \pm 0.00$ & CR \\
\hline 22. & Clariidae & Cat fish/ Magur & Clarias batrachus & $0.99 \pm 0.06$ & $0.89 \pm 0.04$ & $0.82 \pm 0.03$ & $0.77 \pm 0.03$ & $0.70 \pm .0 .02$ & $\mathrm{vU}$ \\
\hline 23. & Heteropneustidae & $\begin{array}{l}\text { Stinging catfish/ } \\
\text { Shingi }\end{array}$ & $\begin{array}{l}\text { Heteropneustes } \\
\text { fossilis }\end{array}$ & $0.98 \pm 0.07$ & $0.93 \pm 0.05$ & $0.84 \pm 0.05$ & $0.83 \pm 0.04$ & $0.80 \pm 0.02$ & LC \\
\hline 24. & Chacidae & Cheka & Chaca chaca & $0.72 \pm 0.06$ & $0.66 \pm 0.04$ & $0.57 \pm 0.03$ & $0.52 \pm 0.03$ & $0.49 \pm .0 .02$ & LR \\
\hline 25. & Olyridae & Gagora catfish / Gobi & Arius gagora & $1.75 \pm 0.07$ & $1.68 \pm 0.05$ & $1.50 \pm 0.05$ & $1.46 \pm 0.04$ & $1.39 \pm 0.02$ & EN \\
\hline \multicolumn{4}{|c|}{ Sub-total } & $34.12 \pm 0.84$ & $31.54 \pm 0.81$ & $29.34 \pm 0.79$ & $27.84 \pm 0.77$ & $25.98 \pm 0.76$ & \\
\hline \multicolumn{10}{|c|}{ Clupidae } \\
\hline 1. & Clupidae & Chapila & Gadusia chapra & $3.50 \pm 0.58$ & $3.25 \pm 0.47$ & $3.11 \pm 0.56$ & $3.01 \pm 0.45$ & $2.88 \pm 0.34$ & EN \\
\hline 2. & Clupidae & Hilsa & Tenualosa ilisha & $1.88 \pm 0.08$ & $1.65 \pm 0.06$ & $1.50 \pm 0.04$ & $1.42 \pm 0.02$ & $1.35 \pm 0.01$ & EN \\
\hline 3. & Clupidae & $\begin{array}{l}\text { Gizzard shad/ } \\
\text { Chapila }\end{array}$ & Gonialosa manmina & $0.82 \pm 0.08$ & $0.79 \pm 0.06$ & $0.76 \pm 0.04$ & $0.75 \pm 0.02$ & $0.64 \pm 0.01$ & EN \\
\hline \multicolumn{4}{|c|}{ Subtotal } & $6.20 \pm 1.64$ & $5.69 \pm 1.53$ & $5.37 \pm 1.48$ & $5.18 \pm 1.44$ & $4.87 \pm 1.38$ & \\
\hline \multicolumn{10}{|c|}{ Eel } \\
\hline 1. & Mastacembeli-dae & Baim & $\begin{array}{l}\text { Mastacembalus } \\
\text { armatus }\end{array}$ & $3.45 \pm 0.11$ & $3.02 \pm 0.10$ & $2.88 \pm 0.08$ & $2.52 \pm 0.07$ & $2.22 \pm 0.06$ & $\mathrm{VU}$ \\
\hline 2. & Synbranchidae & Kuicha & Monopterus cuchia & $2.88 \pm 0.09$ & $2.78 \pm 0.08$ & $2.34 \pm 0.07$ & $2.18 \pm 0.6$ & $2.02 \pm 0.06$ & EN \\
\hline 3. & Mastacembelidae & $\begin{array}{l}\text { Lesser spiny eel/ } \\
\text { Tara baim }\end{array}$ & $\begin{array}{l}\text { Macrognathus } \\
\text { aculeatus }\end{array}$ & $2.84 \pm 0.08$ & $2.81 \pm 0.07$ & $2.54 \pm 0.07$ & $2.41 \pm 0.06$ & $2.42 \pm 0.06$ & EN \\
\hline 4. & Mastacembelidae & One-stripe spiny eel & Macrognatbus aral & $2.58 \pm 0.09$ & $2.44 \pm 0.08$ & $2.35 \pm 0.08$ & $2.20 \pm 0.07$ & $2.03 \pm 0.06$ & LR \\
\hline 5. & Mastacembelidae & $\begin{array}{l}\text { Barred spiny eel/ } \\
\text { Pankal baim }\end{array}$ & $\begin{array}{l}\text { Macrognathus } \\
\text { pancalus }\end{array}$ & $2.55 \pm 0.11$ & $2.50 \pm 0.10$ & $2.44 \pm 0.09$ & $2.33 \pm 0.08$ & $2.12 \pm 0.08$ & EN \\
\hline \multicolumn{4}{|c|}{ Subtotal } & $14.30 \pm 2.55$ & $13.55 \pm 2.40$ & $12.55 \pm 2.40$ & $11.64 \pm 2.30$ & $10.81 \pm 1.88$ & \\
\hline \multicolumn{10}{|c|}{ Prawn } \\
\hline 1. & Palaemonidae & Golda Isa & $\begin{array}{l}\text { Machrobrachiu } \\
\text { rosenbergii }\end{array}$ & $1.90 \pm 0.08$ & $1.77 \pm 0.06$ & $1.69 \pm 0.04$ & $1.48 \pm 0.04$ & $1.40 \pm 0.04$ & EN \\
\hline 2. & Palaemonidae & Gura Isa & $\begin{array}{l}\text { Machrobrachium } \\
\text { biramanicus }\end{array}$ & $4.08 \pm 0.90$ & $3.50 \pm 0.81$ & $3.27 \pm 0.77$ & $3.02 \pm 0.48$ & $2.88 \pm 0.44$ & $\mathrm{DD}$ \\
\hline 3. & Palaemonidae & Gul Isa & $\begin{array}{l}\text { Machrobrachium } \\
\text { malcolmsnii }\end{array}$ & $1.23 \pm 0.72$ & $1.06 \pm 0.66$ & $1.03 \pm 0.55$ & $1.06 \pm 0.44$ & $1.11 \pm 0.36$ & $\mathrm{VU}$ \\
\hline 4. & Palaemonidae & Dimua icha & $\begin{array}{l}\text { Macrobrachium } \\
\text { villosimanus }\end{array}$ & $1.11 \pm 0.29$ & $1.08 \pm 0.22$ & $1.02 \pm 0.08$ & $0.99 \pm 0.08$ & $0.90 \pm 0.07$ & LC \\
\hline 5. & Palaemonidae & $\begin{array}{l}\text { Gura icha or } \\
\text { kuncho chingri }\end{array}$ & $\begin{array}{l}\text { Macrobrachium } \\
\text { lamarrei }\end{array}$ & $0.88 \pm 0.08$ & $0.80 \pm 0.07$ & $0.88 \pm 0.06$ & $0.71 \pm 0.05$ & $0.77 \pm 0.06$ & LR \\
\hline
\end{tabular}




\begin{tabular}{|c|c|c|c|c|c|c|c|c|c|}
\hline 6. & Palaemonidae & $\begin{array}{l}\text { Kaira icha or } \\
\text { beel chingri. }\end{array}$ & $\begin{array}{l}\text { Macrobrachium } \\
\text { dayanum }\end{array}$ & $0.77 \pm 0.08$ & $0.76 \pm 0.05$ & $0.78 \pm 0.05$ & $0.66 \pm 0.07$ & $0.62 \pm 0.04$ & LR \\
\hline 7. & Palaemonidae & Chikna chingri. & $\begin{array}{l}\text { Macrobrachium } \\
\text { idella }\end{array}$ & $1.08 \pm 0.22$ & $1.04 \pm 0.16$ & $1.02 \pm 0.15$ & $1.01 \pm 0.14$ & $1.02 \pm 0.16$ & DD \\
\hline 8. & Palaemonidae & Icha & $\begin{array}{l}\text { Macrobrachium } \\
\text { kempi }\end{array}$ & $0.98 \pm 0.09$ & $0.83 \pm 0.07$ & $0.86 \pm 0.05$ & $0.82 \pm 0.04$ & $0.85 \pm 0.03$ & $\mathrm{VU}$ \\
\hline 9. & Palaemonidae & chingri & $\begin{array}{l}\text { Macrobrachium } \\
\text { superbum }\end{array}$ & $0.99 \pm 0.09$ & $0.90 \pm 0.06$ & $0.91 \pm 0.05$ & $0.90 \pm 0.04$ & $0.92 \pm 0.03$ & LC \\
\hline \multicolumn{4}{|c|}{ Sub-total: } & $13.02 \pm 1.41$ & $11.74 \pm 1.24$ & $11.46 \pm 1.28$ & $10.65 \pm 1.22$ & $10.47 \pm 1.23$ & \\
\hline \multicolumn{10}{|c|}{ Crabs/Snail } \\
\hline 1. & Potamidae & Kakra & Sartoriana spinigera & $2.98 \pm 0.88$ & $2.73 \pm 0.70$ & $2.42 \pm 0.64$ & $2.39 \pm 0.54$ & $2.26 \pm 0.44$ & DD \\
\hline 2. & Grapsidae & Common Kakra & $\begin{array}{l}\text { Lobothelphusa } \\
\text { wood-masoni }\end{array}$ & $2.18 \pm 0.80$ & $1.81 \pm 0.61$ & $1.64 \pm 0.60$ & $1.58 \pm 0.56$ & $1.20 \pm 0.48$ & LR \\
\hline 3. & Grapsidae & Kakra & $\begin{array}{l}\text { Acanthopotamon } \\
\text { martensi }\end{array}$ & $1.48 \pm 0.72$ & $1.33 \pm 0.50$ & $1.28 \pm 0.48$ & $1.16 \pm 0.42$ & $1.09 \pm 0.41$ & $\mathrm{VU}$ \\
\hline 4. & Parathelphusidae & Kakra & $\begin{array}{l}\text { Pyxidognathus } \\
\text { fluviatilis }\end{array}$ & $1.18 \pm 0.70$ & $1.00 \pm 0.64$ & $0.88 \pm 0.66$ & $0.90 \pm 0.60$ & $0.72 \pm 0.54$ & LC \\
\hline 5. & Parathelphusidae & Kakra & $\begin{array}{l}\text { Austrotelphusa } \\
\text { transversa }\end{array}$ & $1.74 \pm 0.61$ & $1.32 \pm 0.45$ & $1.18 \pm 0.40$ & $1.06 \pm 0.42$ & $0.96 \pm 0.35$ & EN \\
\hline 6. & Unionidae & Bivalve & $\begin{array}{l}\text { Lamellidens } \\
\text { marginalis }\end{array}$ & $0.82 \pm 0.24$ & $0.72 \pm 0.21$ & $0.70 \pm 0.18$ & $0.68 \pm 0.15$ & $0.62 \pm 0.12$ & $\mathrm{VU}$ \\
\hline \multicolumn{4}{|c|}{ Sub-total: } & $10.38 \pm 0.50$ & $8.91 \pm 0.41$ & $8.10 \pm 0.28$ & $7.77 \pm 0.25$ & $6.86 \pm 0.21$ & \\
\hline \multicolumn{10}{|c|}{ Tortoise } \\
\hline 1. & Testudinidae & $\begin{array}{l}\text { Elongated Tortoise/ } \\
\text { Kachhap }\end{array}$ & $\begin{array}{l}\text { Indotestudo } \\
\text { elongata }\end{array}$ & $0.26 \pm 0.03$ & $0.20 \pm 0.02$ & $0.17 \pm 0.02$ & $0.14 \pm 0.01$ & $0.07 \pm 0.01$ & CR \\
\hline 2. & Testudinidae & $\begin{array}{l}\text { Asian Giant Tortoise/ } \\
\text { Chila Kachhap }\end{array}$ & Manouria emys & $0.30 \pm 0.05$ & $0.31 \pm 0.04$ & $0.28 \pm 0.05$ & $0.20 \pm 0.03$ & $0.10 \pm 0.02$ & EN \\
\hline 3. & Geoemydidae & $\begin{array}{l}\text { River Terrapin/ } \\
\text { Bodo Kaitta }\end{array}$ & Batagur baska & $0.11 \pm 0.02$ & $0.10 \pm 0.01$ & $0.11 \pm 0.01$ & $0.06 \pm 0.01$ & $0.03 \pm 0.00$ & CR \\
\hline 4. & Geoemydidae & $\begin{array}{l}\text { Painted Roofed } \\
\text { Turtile/Dhoor } \\
\text { Kachim }\end{array}$ & Batagur dongoka & $0.12 \pm 0.02$ & $0.12 \pm 0.21$ & $0.08 \pm 0.16$ & $0.04 \pm 0.06$ & $0.02 \pm 0.07$ & EN \\
\hline 5. & Geoemydidae & $\begin{array}{l}\text { Oldhams Leaf } \\
\text { Turtile/Pata Kachim }\end{array}$ & Cyclemys oldhami & $0.11 \pm 0.22$ & $0.08 \pm 0.02$ & $0.04 \pm 0.01$ & $0.01 \pm 0.01$ & $0.00 \pm 0.00$ & $\mathrm{E}$ \\
\hline 6. & Geoemydidae & $\begin{array}{l}\text { SpottedTurtile/ } \\
\text { Kala Kachim }\end{array}$ & $\begin{array}{l}\text { Geoclemys } \\
\text { bamiltonii }\end{array}$ & $0.17 \pm 0.02$ & $0.14 \pm 0.02$ & $0.09 \pm 0.01$ & $0.07 \pm 0.01$ & $0.08 \pm 0.01$ & CR \\
\hline 7. & Geoemydidae & $\begin{array}{l}\text { Brahminy River } \\
\text { Turtile/Kali Kaitta }\end{array}$ & Hardella thurjii & $0.28 \pm 0.11$ & $0.21 \pm 0.05$ & $0.16 \pm 0.06$ & $0.14 \pm 0.02$ & $0.07 \pm 0.01$ & EN \\
\hline 8. & Geoemydidae & $\begin{array}{l}\text { Shila Kachhap } \\
\text { tricarinata }\end{array}$ & Melanocheelys & $0.20 \pm 0.02$ & $0.18 \pm 0.01$ & $0.14 \pm 0.01$ & $0.11 \pm 0.01$ & $0.07 \pm 0.01$ & $\mathrm{EN}$ \\
\hline 9. & Geoemydidae & $\begin{array}{l}\text { Snail Eating Turtile/ } \\
\text { Kali Kachhap }\end{array}$ & $\begin{array}{l}\text { Melanocheelys } \\
\text { trjunga }\end{array}$ & $0.18 \pm 0.02$ & $0.11 \pm 0.02$ & $0.07 \pm 0.01$ & $0.02 \pm 0.00$ & $0.00 \pm 0.00$ & E \\
\hline 10. & Geoemydidae & Bengal Eyed Turtile & Morenia petersi & $0.09 \pm 0.01$ & $0.07 \pm 0.01$ & $0.05 \pm 0.01$ & $0.03 \pm 0.00$ & $0.0 \pm 0.00$ & $\mathrm{E}$ \\
\hline 11. & Geoemydidae & $\begin{array}{l}\text { Indian Turtile/ } \\
\text { Kori Kaitta }\end{array}$ & Pangshura tecta & $0.14 \pm 0.02$ & $0.13 \pm 0.01$ & $0.10 \pm 0.01$ & $0.08 \pm 0.01$ & $0.06 \pm 0.01$ & CR \\
\hline 12. & Geoemydidae & $\begin{array}{l}\text { Tent Turtile/ } \\
\text { Majhari Kaitta }\end{array}$ & Pangshura tentoria & $0.07 \pm 0.01$ & $0.08 \pm 0.01$ & $0.06 \pm 0.00$ & $0.05 \pm 0.01$ & $0.04 \pm 0.00$ & $\mathrm{EN}$ \\
\hline 13. & Trionychidae & $\begin{array}{l}\text { Ganges Turtile/ } \\
\text { Khalua Kachim }\end{array}$ & $\begin{array}{l}\text { Aspideretes } \\
\text { gangeticus }\end{array}$ & $0.35 \pm 0.03$ & $0.34 \pm 0.02$ & $0.28 \pm 0.04$ & $0.20 \pm 0.03$ & $0.11 \pm 0.01$ & $\mathrm{VU}$ \\
\hline 14. & Trionychidae & $\begin{array}{l}\text { Narrow Headed } \\
\text { Turtile/Chitra } \\
\text { Kachhim }\end{array}$ & Chitra indica & $0.36 \pm 0.02$ & $0.31 \pm 0.01$ & $0.27 \pm 0.02$ & $0.22 \pm 0.01$ & $0.20 \pm 0.01$ & EN \\
\hline 15. & Trionychidae & Spotted Flapshell & Lissemys punctata & $0.60 \pm 0.08$ & $0.61 \pm 0.07$ & $0.54 \pm 0.05$ & $0.43 \pm 0.04$ & $0.33 \pm 0.03$ & EN \\
\hline \multirow{2}{*}{\multicolumn{4}{|c|}{ Sub-total }} & $3.34 \pm 0.15$ & $2.99 \pm 0.18$ & $2.44 \pm 0.14$ & $1.80 \pm 0.10$ & $1.25 \pm 0.10$ & \\
\hline & & & & $202.99 \pm 13.42$ & $188.35 \pm 12.77$ & $178.96 \pm 12.33$ & $168.72 \pm 11.79$ & $158.43 \pm 11.34$ & \\
\hline
\end{tabular}


However, the total catch differed significantly $(\mathrm{P}<0.05)$ among the five years Table 3 shows the existing structure of wild lives.

A decreasing trend in catch of the river was clearly pronounced within five years which was similar to the report of Chakraborty and Mirza (2010) and Moyle and Leidy (1992). A total of fifteen species of fresh water turtles were found in the Kongsha River and its floodplain. During winter season, turtles (Morenia petersi, Melanocheelys trjuuga and Cyclemys oldhami) were mostly caught in the river and its flood plains. Khan (1982) reported that Pangshura tecta are mainly distributed between the stretches of the Ganges River and the Brahmaputra River. Bengal Eyed turtle, Morenia petersi was found in the rivers and its flood plains wetland. Das (1991) mentioned its occurrence in Assam of India. Morenia petersi was regularly caught by fishermen and expert tribal hunters. Unfortunately, three important species of turtles became rare in their existence as per the catch data, within five years study period. The production of all the recorded groups decreased during study, it was pronounced more for reptiles.

The population of bivalve, Lamellidens marginalis as found in the river and its flood plains has also been decreasing which is considered with the observation of Ali (1991) and Chakraborty (2011). During study period, fresh water pearl bearing mussels (Bivalve, Lamellidens marginalis) were identified in the river. Shells of bivalve were utilized by rural people for production of lime which was utilized in aquaculture and agriculture land, and consumed with betel leaves and nuts.

The wildlife comprises amphibians (Bufo melanostictus, Rana tigerina, Rana limnocharis, Rana cyanophyctis and Salamandra salamandra etc.) aves (whistling duck, great crested grebe, great cormorant, red crested pochard, water cock, swamphen, great black headed gull, gray-headed fish eagle, curlew, spotted redshank etc.) and mammals (musk shrew, fishing cat, small Indian jackal, flying fox etc.) were previously reported by Chakraborty et al. (2019).

The experiment clearly specifies that the aquatic lives of the river were subjected to over exploitation resulting in gradual decline in their catch. The stock of aquatic animals is reducing due to pollution and destructive fishing practices (Mazid and Hussain, 1995; Chakraborty, 2011; Chakraborty et al., 2021a). Indiscriminate killing of fish occurred due to the use of pesticides in improper doses (Prakash and Verma, 2020), use of forbidden chemicals, and aerial spray of chemicals as used in paddy field which was very much similar to the observation of Chakraborty (2011) and Mazid (2002). Intervention to control floods, adoption of new agricultural technologies and construction of road networks altered the ecology of rivers and its flood plains significantly which supported the views of Khan (1993) and Ali (1991). Decreased stock of the wild brood fishes in their breeding ground also resulted in a reduction of biodiversity as noted by Nishat (1993) and Zaman (1993).

\section{CONCLUSION}

For better management to save the stock of aquatic species in the river, a team of local management committee like Hilsa fisheries management technology is needed to develop a working frame-work. The deeper area of the river must be declared as a sanctuary to protect the aquatic lives, streaked enforcement of fish Act1950 in the river, ensured stopping unplanned construction of flood control embankments, drainage system and sluice gates, conversion of inundated land of floodplain to cropland (reducing water area); and controlling use of pesticides and agrochemicals in the floodplains of the river can save the ecosystem health of the river. The sustained production level from the river would also be ensured livelihood of the fishers.

\section{ACKNOWLEDGMENT}

The authors highly gratefully acknowledged to the Upazilla Fisheries Office of Purbadhola, Durgapur, Sadar Netrokona and Bharhatta, Netrokona, Department of Fisheries, Bangladesh for kind support and cooperation.

\section{REFERENCES}

1. Alam G.N. (1996). Floodplain fisheries development in Bangladesh. Fisheries News. 4(1): 3-4.

2. Ali M.M., Hossain M.B., Rahman M.A. and Habib A. (2014). Diversity of Fish Fauna in the 
Chitra River of Southwestern Bangladesh: Present Status, Threats and Recommendations for Conservation. Asian Journal of Applied Science. 7(7): 635-643.

3. Ali M.Y. (1991). Towards sustainable development: fisheries resources of Bangladesh International union for conservation of nature and natural resources. The World Conservation Union. National Conservation Strategy of Bangladesh and Bangladesh Agricultural Research Council. 96p.

4. Allendrof F.W. (1988). Conservation biology of fishes. Conservation Biology 2: 145-148.

5. APHA (1998). Standard methods for the examination of water and wastewater, $20^{\text {th }}$ edition, American Public Health Association, Washington, DC.

6. Arya S. (2021). Freshwater Biodiversity and Conservation Challenges: A Review. International Journal of Biological Innovations. 3 (1): 74-78. https://doi.org/ 10.46505/IJBI.2021.3106

7. Ashok K.V. (2021). Influence of climate change on balanced ecosystem, biodiversity and sustainable development: An overview. International Journal of Biological Innovations. 3(2):331-337. https://doi.org/ 10.46505/IJBI.2021.3213

8. Boyd C.E. (1982). Water Quality Management for Pond Fish Culture. Elsevier, The Netherlands. 318p.

9. Cairns M.A. and Lackey R.T. (1992). Biodiversity and management of natural resources: the issues. Fisheries, Bulletin of the American Fisheries Society. 17(3): 6-10.

10. Chakraborty B. Kumar (2009). Aquatic biodiversity of Someswari and Nethai River and Gharia and Nidaya Beel of Northern Bangladesh. In: Takumi K. Nakamura (ed.). Aquaculture Research Progress, Nova Science Publishers, New York, USA. 3231-3268p.

11. Chakraborty B.K. (2011). Present Status of Biodiversity in Bogajan Beel in Northern Bangladesh J. Fish. Soc. Taiwan 38(4): 277300.
12. Chakraborty, B.K., Wahab A., Rahman J. and Hossain A. (2019). Conservation and promotion of Major Cat fishes and Chital in the Padma River system. International Journal of Oceanography \& Aquaculture. Australia. 4(3): 000193.

13. Chakraborty B.K. (2021a) Production of aquatic lives and biodiversity status of Ubdhakhali River in Bangladesh. Progressive Research: An International Journal. 16 (2):8390.

14. Chakraborty B.K. (2021b). Induction of spawning and nursing pangas, Pangasianodon hypophthalmus (Sauvage, 1878) under hatchery system. International Journal of Biological Innovations. 3 (2): 264-270. https://doi.org/10.46505/IJBI.2021.3203

15. Chakraborty B.K. and Mirza M.J.A. (2007). Aquatic biodiversity of Gharia Beel of Northern Bangladesh. J. Crop and Weed, India. 3: 23-34.

16. Chakraborty B.K. and Mirza M.J.A. (2010). Aquatic biodiversity of Someswari River in Bangladesh. Asian Fisheries Science. 23:174193.

17. Chakraborty B.K., Bhattacharjee S. and Muniya S. (2021a). A Study of aquatic biodiversity of Shuthi-Shaiduli river of Bangladesh. International Journal of Biological Innovations. 3(1): 58-67.

18. Chakraborty B.K., Verma A.K. and Muniya S. (2021b). Present Status of Aquatic Resource and Its Catch of Mogra River in Bangladesh. Sustainable Marine Structures. 3 (2): 26-38. http://dx.doi.org/10.36956/sms.v3i2.436

19. Chakraborty B.K., Shahroz M.H., Bhuiyan A.B., Bhattacharjee S. and Chattoraj S. (2019). Status of Indian major carps spawns in the Halda River along with marketing and economic condition of the Fishers and related collectors. International Journal of Biological Innovations. 1 (2):40-50. https://doi.org/ 10.46505/IJBI.2019.1202.

20. Clesceri L.S., Greenberg A.E. and Trussell R.R. (1989). Standard methods of the examination of water and wastewater $\left(17^{\text {th }}\right.$ ed.). American Public Health Association, 
American Water Works Association and Water Pollution Control Federation, 1015 Washington D. C., USA 20036, 10-203.

21. Das I. (1991). Color guide to the turtles and tortoises of the Indian sub-continent. $\mathrm{R} \& \mathrm{~A}$ publishing Ltd.

22. Disaster E. (1990). Floodplain protection in Central Europe. World Wildlife Found (WWF) Institute of Floodplains Ecology Visiting Card 31/90, Germany.

23. Efe Ogidiaka and Bemigho I. R. (2021). Fish Fauna Composition, Abundance and Distribution of Forcados River Estuary. International Journal of Biological Innovations. 3 (1): 139-147. https://doi.org/ 10.46505/IJBI.2021.3113

24. Galib S.M., Samad M.A., Kamal M.M., Haque M.A. and Hasan M.M. (2009). A Study on Fishing Gears and Methods in the Chalan Beel of North-West Bangladesh. Journal of Environmental Science \& Natural Resources. 2(2): 213- 218.

25. Goswami D. N., Gautam Y.P. and Kumar A. (2021). Evaluation of Ganges water quality and its suitability for Agriculture use from Rishikesh to Prayagraj, India. International Journal of Biological Innovations. 3(2):417421. https://doi.org/10.46505/IJBI.2021.3225.

26. Haroon A.K.Y., Halder G.C., Rahman S.L., Razzaque M.A., Alam M. and Amin S.M.N. (2002). Sylhet-mymensingh basin fish stock assessment. Final Report. Bangladesh Fisheries Research Institute, Reverine Station, Chandpur, Bangladesh 81p.

27. Hussain M. (1999). Design of two standard steel body fishing crafts for all season operation in the Bay of Bengal, National Marine Fisheries Seminar. Edited by Bhuiyan AL and Chowdhury AK.

28. IUCN (1998). List of threatened animals of Bangladesh. Paper presented in the Special Workshop on Bangladesh Red Book of Threatened Animals, 22 February 1998, Dhaka, Bangladesh. 13p.

29. IUCN (2000). Red book of threatened fishes of Bangladesh. IUCN- The World Conservation Union xii+116p.
30. Khan H.R. (1993). Water development activities and their impacts on wetlands. P. 23-32. In: A. Nisat, Z. Hossain, M. K. Roy, and Ansarul Karim (eds.). Freshwater wetlands in Bangladesh: issues and approaches for management. IUCN, Gland Switzerland. $\mathrm{xii}+283 \mathrm{p}$.

31. Khan M.A.R. (1982). Chelonians of Bangladesh and their conservation. Journal of Bombay Natural History Society. 79 (I): 110116.

32. Marichamy G., Shanker, S., Saradha A., Nazar, A.R. and Badhul Haq, M.A. (2011). Proximate composition and bioaccumulation of metals in some finfishes and shellfishes of Vellar Estuary (South East Coast of India). Eur. J. Exp. Biol., 1: 47-55.

33. Mathew P.W. (1975). Limnology and productivity of Govindgarh Lake, Maddya Prodesh, India. Journal of Inland Fisheries Society, India. 11: 16-24.

34. Mazid M.A. (2002). Development of fisheries in Bangladesh: plans and strategic for income generation and poverty alleviation. Fisheries Research Institute, Mymensingh, Bangladesh. 78-79p.

35. Mazid M.A. and Hossain M.S. (1995). Development of fisheries resources in floodplains. FRI publication No. 12. Fisheries Research Institute, Mymensingh, Bangladesh.

36. Moyle P.L. and Leidy R.A. (1992). Loss of biodiversity in aquatic ecosystem: evidence from fish fauna. In: P.L. Fielder and H.L. Jani (eds). Conservation of Biology: the theory and practice of nature conservation, preservation and management. Chapman and Hall, New York, USA. 562p.

37. Nasrin Baby S. (2012). "Kangsa River". In Sirajul Islam and Ahmed A. Jamal (ed.). Banglapedia: National Encyclopedia of Bangladesh (Second ed.). Asiatic Society of Bangladesh.

38. Nishat A. (1993). Freshwater wetlands in Bangladesh: status and issues. P. 9-22 In: A. Nishat Z. Hossain, M. K. Roy, and Ansarul Karim (eds.). Freshwater wetlands in 
Bangladesh: Issues and Approaches for management. IUCN, Gland Switzerland. xii $+283 p$.

39. Noss R. F. (1990). A regional landscape approach to maintain diversity. Bioscience. 33: 700-706.

40. Okyere I. and Denis W. (2011). Aheto and Joseph aggrey-fynn. Eur. J. Exp. Biol., 1: 178188.

41. Prakash S. (2021). Impact of Climate change on Aquatic Ecosystem and its Biodiversity: An overview. International Journal of Biological Innovations. 3(2):312-317. https://doi.org/10.46505/IJBI.2021.3210

42. Prakash Sadguru and Verma A. K. (2020). Effect of Organophosphorus Pesticides on Biomolecules of Freshwater Fish, Heteropneustes fossilis (Bloch). Indian Journal of Biology. 7(2):65-69.

43. Rahman M.S. (1992). Water quality management in aquaculture. BARC Prokashana, 66, Mohakhali, Dhaka 1212, Bangladesh 84p.

44. Sarker S.U. (1993). Faunal diversity and their conservation in freshwater wetlands. In Freshwater wetlands in Bangladesh issues and approaches for management. IUCN, The world Conservation Union. 105-122p.

45. Shannon C.E. (1948). A mathematical theory of communication. Bell System Tec. J., 27: 379656.
46. Sugunan V.V. and Bhattacharya B.K. (2000). Ecology and fisheries of beels in Assam. Bull.No.104, CIFRI, Barrackpore-743101, West Bengal 66p.

47. Thiel R., Sepulveda A., Kafemann R. and Nellen W. (1995). Environmental factors as forces structuring the fish community of the Elbe estuary. J. Fish Biol., 46: 47-69.

48. Verma A.K. (2018). Ecological Balance: An Indispensable Need for Human Survival. Journal of Experimental Zoology, India. 21 (1): 407-409.

49. Verma A.K. (2019). Sustainable Development and Environmental Ethics. International Journal on Environmental Sciences. 10 (1): 1-5.

50. Verma A.K. and Prakash S. (2020). Status of Animal Phyla in different Kingdom Systems of Biological Classification. International Journal of Biological Innovations. 2 (2): 149154. https://doi.org/ 10.46505/ IJBI. 2020.2211 .

51.Zaman S.M.H. (1993). Agricultural development and sustainability of wetlands. pp.63-178 In: A. Nishat Z. Hossain, M.K. Roy, and A. Karim (eds.). Freshwater wetlands in Bangladesh: Issues and Approaches for management. IUCN, Gland Switzerland. xii +283p.

52. Zar J.H. (1984). Biostatistics. Prentice-Hall, Inc. Englewood Cliffs, New Jersey, USA. 718p. 